\title{
Functional significance of PMM2 mutations in mildly affected patients with congenital disorders of glycosylation la
}

Vibeke Westphal, $P \mathrm{hD}^{1}$, Sandra Peterson ${ }^{1}$, Marc Patterson, $M D^{2}$, Anne Tournay, MD ${ }^{3}$, Andrea Blumenthal, $M D^{4}$, Eileen P. Treacy, $M D^{4}$, and Hudson H. Freeze, $P h D^{1}$

\begin{abstract}
Purpose: Congenital disorders of glycosylation (CDG) result from mutations in N-glycan biosynthesis. Mutations in phosphomannomutase (PMM2) cause CDG-la. Here, we report four clinically mild patients and their mutations in PMM2. Methods: Analysis of the PMM2 cDNA and gene revealed the mutations affecting the glycosylation efficiency. Results: The patients have 30\% to 50\% normal PMM activity in fibroblasts due to different mutations in PMM2, and we studied the effect of each mutation on the PMM activity in a Saccharomyces cerevisiae expression system. Conclusions: Each patient carried a severe mutation that decreased the PMM activity to less than $10 \%$ as well as a relatively mild mutation. A new mutation, deletion of base 24 , changed the reading frame. The C9Y, C241S, and L32R mutations showed $27 \%$ to $45 \%$ activity when expressed in the eukaryotic expression system, and the more severe D148N was shown to be thermolabile. Genet Med 2001:3(6):393-398.
\end{abstract}

Key Words: congenital disorders of glycosylation, phosphomannomutase, genotype-phenotype, oligosaccharide

Congenital disorders of glycosylation (CDG) are autosomal recessive metabolic disorders resulting from mutations in both alleles of any of several different genes in the N-linked oligosaccharide pathway. CDG-Ia is by far the most common and is caused by mutations in PMM2 that codes for phosphomannomutase (mannose-6-phosphate $\rightarrow$ mannose-1-phosphate). ${ }^{1}$ Mutations in this gene decrease the supply of intracellular GDP-Man and limit the amount of lipid-linked oligosaccharide (LLO) precursor available for protein glycosylation. ${ }^{2}$ This limitation leads to unoccupied glycosylation sites on some proteins. Likewise, patients with CDG-Ib, which is caused by defects in phosphomannose isomerase (MPI or PMI) also make insufficient GDP-Man for complete glycosylation. ${ }^{2}$ CDG-Ic is caused by mutations in $A L G 6,{ }^{3-5}$ which encodes an $\alpha-1,3$ glucosyltransferase that adds the first glucose residue to the LLO precursor. Although CDG-Ic patients make a normal amount of LLO, nonglucosylated precursor is a poor substrate for the oligosaccharyl transferase, and this too leads to unoccupied glycosylation sites. ${ }^{6-8}$ Each of these defects can be detected easily by altered isoelectric focusing patterns of serum

From ${ }^{1}$ The Burnham Institute, Glycobiology Program, La Jolla, California; ${ }^{2}$ Department of Pediatric Neurology, The Neurological Institute, New York, New York; ${ }^{3}$ UCLA Pediatric Neurology, Los Angeles, California; and the ${ }^{4}$ Division of Biochemical and Medical Genetics at the Montreal Children's Hospital and Department of Human Genetics at McGill University, Montreal, Quebec, Canada.

Hudson Freeze, PhD, The Burnham Institute, Glycobiology Program, 10901 North Torrey Pines Road, La Jolla, CA 92037.

S. Peterson's present address: Genoptix, 3398 Carmel Mountain Road, San Diego, CA 92121. Dr. Westphal's current address: Novo Nordisk A/S, Denmark.

Received: May 24, 2001.

Accepted: June 28, 2001. transferrin and biochemically characterized by enzymatic assays and/or altered $\left[2-{ }^{3} \mathrm{H}\right]$ mannose labeling patterns from patient fibroblasts. ${ }^{9}$

The symptoms of CDG-Ia vary, but typical features such as mental and psychomotor retardation, variable dysmorphology (inverted nipples, fat pads), internal strabismus, feeding problems, failure to thrive, as well as cerebellar hypoplasia are often seen. ${ }^{10-13}$ The disease can have a lethal outcome in early childhood. ${ }^{14,15}$ Over 50 different mutations have to date been identified in PMM patients, ${ }^{15}$ and a recent study shows some correlation of the clinical severity of mildly affected CDG-Ia patients with the residual activity of PMM. ${ }^{16}$

In this study, we analyze four untyped CDG patients (two of them siblings). We find that each patient has a functional PMM2 allele with mild mutations inherited from one parent and a severely deficient $P M M 2$ allele inherited from the other parent. This leads to $30 \%$ to $50 \%$ residual PMM activity in the patients, but analysis of the patients' fibroblasts showed normal LLO and glycosylation efficiency.

\section{MATERIALS AND METHODS}

\section{Media and materials}

Most of the materials were obtained from Sigma Chemical Co. (St. Louis, MO) except for the following: minimal essential medium ( $\alpha$-MEM and DMEM) (Gibco BRL, Baltimore, MD), RPMI 1604 medium (Irvine Scientific, La Jolla, CA), fetal bovine serum (Hyclone Laboratories, Logan, UT), and Microsorb-MV $\mathrm{NH}_{2}$ high performance liquid chromatography (HPLC) column (Varian Instruments, Walnut Creek, CA). Radiolabel $\left[2-{ }^{3} \mathrm{H}\right]$ mannose $(20 \mathrm{Ci} / \mathrm{mmol})$, was from American 
Radiolabeled Chemicals, Inc. (St. Louis, MO). Tran ${ }^{35}$ S-Label $(1,000 \mathrm{Ci} / \mathrm{mmol})$ was obtained from ICN Pharmaceuticals, Inc. (Costa Mesa, CA). Restriction enzymes and T4 DNA ligase were from Promega (Madison, WI). Oligonucleotides were from Genbase (San Diego, CA). Sequencing was performed using BigDye sequencing kit on an ABI 377 DNA sequencer, both from Applied Biosystems (Foster City, CA). Saccharomyces cerevisiae and Escherichia coli were grown in standard YPD, SC, and LB media. ${ }^{17,18}$ The sec $53^{\text {ts }}$ S. cerevisiae strain RSY 12 (Mata sec53-6 leu2-3,112 ura3-52) ${ }^{19}$ was a kind gift from Dr. Randy Schekman.

\section{Analysis of serum transferrin}

Isoelectric focusing (IEF) analysis of transferrin was done using sera from the patients; defined cases of CDG-Ia, -Ib, and -Ic; as well as normal controls as described previously. ${ }^{20}$

\section{Enzyme assays}

PMI (EC 5.3.1.8) and PMM (EC 5.4.28) assays were carried out as described previously. ${ }^{20-23}$

\section{Radioactive labeling}

Labeling with $\left[2-{ }^{3} \mathrm{H}\right]$ mannose and isolation and characterization of $\left[2-{ }^{3} \mathrm{H}\right]$ mannose-labeled LLO and oligosaccharides from glycoproteins were done essentially as described previously. ${ }^{20,24}$

\section{Sequence analysis of the cDNA and genomic DNA}

Extractions of total RNA and DNA, first-strand PCR, amplification, purification, and sequencing analysis of the PMM2 gene were done as described previously. ${ }^{25}$

\section{Expression of patient PMM alleles}

Subcloning and transformation of E. coli and yeast were carried out using standard procedures. ${ }^{18}$ Cloning and expression of the various PMM alleles was essentially done as described. ${ }^{25}$ This method resulted in the plasmids pWE313 encoding normal wild-type PMM, pWE219 encoding $\Delta \mathrm{c} 24$, pWE314 encoding L32R, pWE222 encoding C9Y, pWE223 encoding D148N, pWE505 encoding C241S, and pWE516 encoding R123Q PMM. The analysis of the transformants was done as described. ${ }^{25}$

\section{RESULTS}

\section{Patient description}

All four patients had developmental delay associated with hypotonia and esotropia, but with less severe neurologic and cutaneous manifestations than typically seen in CDG-Ia patients. ${ }^{11,26-28}$ Patients 2 and 3 showed signs of periodic liver insufficiency as sometimes seen in other CDG patients, ${ }^{1,11,29,30}$ and they also showed slower postnatal growth velocity based on normal values of height and weight. All the children have made developmental progress while under observation, but remain moderately delayed by comparison with their peers. Other than these features, they have few medical problems.
Treatment with oral mannose (patients 1 and 2), $0.15 \mathrm{mg} / \mathrm{kg}$ PO QID for 12 months, did not improve plasma glycoproteins, although development progressed during this period. The clinical data are summarized in Table 1.

IEF of serum transferrin showed a pattern typical of CDG-I. The patients had increased levels of a- and disialotransferrin, but the ratio between normal glycosylated and asialotransferrin was higher in Patient 1 compared with the others (data not shown). Thus, further tests were conducted.

\section{Assays of PMM and PMI activity}

Fibroblasts from three of the patients were assayed for PMI and PMM activity. Due to the familiar relations to Patient 3, the tests were not performed on Patient 4 to avoid unnecessary stress to the patient. The patients showed normal levels of PMI activity (data not shown). However, the PMM activity was impaired, although not as severely as usually observed for the ethnically matched CDG-Ia patients ${ }^{21,22,31-33}$ (Table 2) who show less than 15\% normal activity. Assays were initially done at $25^{\circ} \mathrm{C}$, but the surprisingly high activities in the patient's and some parent's cells suggested that an assay temperature of $37^{\circ} \mathrm{C}$ would be more relevant and perhaps show thermolability. However, assays at both temperatures gave essentially the same amount of residual activity compared with control.

Each of our patients had at least $27 \%$ residual activity when compared with a parallel control analyzed simultaneously. The parents were asymptomatic, and one parent had 50\% to $60 \%$, and the other $70 \%$ to $100 \%$ normal PMM activity. The residual activity in the patient was not substantially lower than the lowest activity in one parent.

\section{$\left[^{3} \mathrm{H}\right]$ Mannose labeling of fibroblasts}

$\left[2-{ }^{3} \mathrm{H}\right]$ Mannose metabolic labeling of CDG fibroblasts usually shows decreased incorporation into proteins and altered LLO structures. 3,5,6,20,34-37 This finding was not seen in Patients 1 and 2. The LLO pattern was normal, consisting almost entirely of $\mathrm{Glc}_{3} \mathrm{Man}_{9} \mathrm{GlcNAc}_{2}$ (Fig. 1). Furthermore, both these patients incorporated essentially normal amounts of $\left[2-{ }^{3} \mathrm{H}\right]$ mannose into protein when normalized to protein content or ${ }^{35} \mathrm{~S}$-amino acid incorporation during labeling (Fig. 1, boxed numbers in bold). Based on previous studies, these results suggested that our mildly affected patients did not have the cellular biochemical features typical of previously known CDG defects. LLO analysis was not done for Patients 3 and 4.

\section{Mutations in PMM2 and their consequences}

Using the cDNA obtained from RT-PCR as well as genomic DNA, the PMM2 sequence was analyzed in the patients and available parents. All patients had two heterozygous mutations. Patient 1 was heterozygous for $722 \mathrm{G}>\mathrm{C}$ resulting in C241 changed to a serine on the protein level and 368G $>$ A resulting in R123Q in the PMM protein. The first mutation was inherited from the mother and the latter from the father. Patient 2's cDNA showed 26G>A (resulting in C9Y in the protein) and $442 \mathrm{G}>\mathrm{A}$ (resulting in $\mathrm{D} 148 \mathrm{~N}$ in the protein), the paternal and maternal allele, respectively. Patients 3 and 4 had 
Table 1

Clinical features of CDG-I patients ${ }^{a}$

\begin{tabular}{|c|c|c|c|c|}
\hline & Patient 1 & Patient 2 & Patient 3 & Patient 4 \\
\hline Sex & Female & Male & Male & Female \\
\hline Family history & - & - & Brother to Patient 4 & Sister to Patient 3 \\
\hline Pregnancy complications & Maternal sinusitis & Varicella at 7 months & Uneventful pregnancy & Uneventful pregnancy \\
\hline Height/weight & Normal & Low & Low & Normal \\
\hline Birth weight (g) & 3,800 & 3,060 & 3,250 & 3,500 \\
\hline Congenital hypotonia & + & + & + & - \\
\hline Esotropia & $+(5$ months $)$ & + (birth) & + (birth) & $+(2-3$ months $)$ \\
\hline Microcephaly & - & $+($ congenital $)$ & - & - \\
\hline Ataxia & + & + & + & + \\
\hline Titubation & + & + & + & + \\
\hline Development & $\begin{array}{l}2 \text { years: } 20 \text { words, short } \\
\text { sentences }\end{array}$ & 3 years: 8 words, 40 signs & $\begin{array}{l}4 \text { years: }>250 \text { words, complete } \\
\text { sentences }\end{array}$ & $\begin{array}{l}7 \text { years: dysarthric, } \\
\text { repeating Grade } 1 \\
\text { with teaching assistant }\end{array}$ \\
\hline GE reflux & + & + & - & - \\
\hline Hydronephrosis & - & + & - & - \\
\hline Lipodystrophy & - & + & - & - \\
\hline Inverted nipples & + & - & - & - \\
\hline MRI head & $\begin{array}{l}\text { Enlarged subarachnoid spaces } \\
\text { and cisterna magna; slight } \\
\text { cerebellar asymmetry, but no } \\
\text { hypoplasia or atrophy }\end{array}$ & $\begin{array}{l}\text { Mild atrophy of the } \\
\text { cerebellar vermis; brain } \\
\text { parenchyma and } \\
\text { ventricular configuration } \\
\text { are normal }\end{array}$ & $\begin{array}{l}\text { Hypoplasia of the posterior } \\
\text { mid-cerebellar vermis }\end{array}$ & $\begin{array}{l}\text { Hypoplasia of the } \\
\text { cerebellar } \\
\text { hemispheres and } \\
\text { vermis }\end{array}$ \\
\hline EEG & Normal (wake and sleep) & Normal & Normal & Normal \\
\hline
\end{tabular}

$\bar{a}+$, present; -, absent.

Table 2

PMM enzyme activity $^{a}$

\begin{tabular}{lcc}
\hline Fibroblasts & $\begin{array}{c}\text { PMM specific activity } \\
\left.\text { (assay run at } 25^{\circ} \mathrm{C}\right) \\
\text { nmol/min/mg }\end{array}$ & $\begin{array}{c}\text { PMM specific activity } \\
\left.\text { (assay run at } 37^{\circ} \mathrm{C}\right) \\
\text { nmol/min/mg }\end{array}$ \\
\hline Control $(n=9)$ & $5.1 \pm 1.6(100)$ & $7.5 \pm 1.4(100)$ \\
Patient 1 & $2.4 \pm 0.6(47)$ & $3.8 \pm 0.9(51)$ \\
Mother-Pt. 1 & $5.3 \pm 1.8(104)$ & $7.4 \pm 2.0(99)$ \\
Father-Pt. 1 & $3.7 \pm 1.5(73)$ & $4.5 \pm 0.6(60)$ \\
Patient 2 & $2.2 \pm 0.2(43)$ & $2.9 \pm 0.7(39)$ \\
Mother-Pt. 2 & $3.1 \pm 0.7(61)$ & $4.5 \pm 0.9(60)$ \\
Father-Pt. 2 & $3.9 \pm 0.5(76)$ & $6.1 \pm 1.1(81)$ \\
Patient 3 & $1.4 \pm 0.4(27)$ & N.D. \\
CDG-Ia $(n=8)$ & $0.7 \pm 0.5(14)$ & $1.0 \pm 0.6(13)$ \\
\hline
\end{tabular}

${ }^{a}$ Extracts from fibroblasts of healthy control $(n=9)$, Patient 1 and parents and Patient 2 and parents as well as established CDG-Ia patients $(n=8)$ were analyzed for PMM activity. Values are the average of at least three independent experiments $\pm \mathrm{SD}$. The assay was done at $25^{\circ} \mathrm{C}$ and $37^{\circ} \mathrm{C}$, and the numbers in parentheses indicate the percent of normal activity.

identical mutations. The deletion of base $\mathrm{C} 24$ changed the reading frame, and mutations $95 \mathrm{~T}>\mathrm{G}$ and $96 \mathrm{~A}>\mathrm{C}$ affected the same codon changing L32 to an arginine. Because these muta- tions seemed to have a very mild effect on the PMM function and did not affect the glycosylation or LLO pattern in at least patients 1 and 2, we wanted to test the functional consequences of each gene alteration. Each allele was recloned into a yeast expression vector and transformed into a $\sec 53^{\text {ts }}$ yeast strain with a temperature sensitive mutation in the essential PMM2 homolog SEC53..$^{38}$ This strain fails to grow at $30^{\circ} \mathrm{C}$, but can be rescued by introduction of the SEC53 gene. ${ }^{19,39}$ Figure 2 shows the ability of the various alleles to rescue the sec $53^{\text {ts }}$ strain at the two restrictive temperatures $30^{\circ} \mathrm{C}$ and $37^{\circ} \mathrm{C}$ (Figure $2 \mathrm{~A}$ and $\mathrm{B}$, respectively). Wild-type human $P M M 2$ is fully capable of rescuing the strain at both temperatures (Fig. 2A and B; lane 1). Interestingly, one of the patient's alleles is also able to fully complement the growth defect, whereas the other allele is virtually ineffective (Fig. 2; lanes 2-7) and comparable to a strain completely lacking PMM activity (Fig. 2; lane 8). Both sets of plates were incubated at $37^{\circ} \mathrm{C}$ for 2 days ( 40 hours) before one set was transferred to $30^{\circ} \mathrm{C}$. After transfer, the maternal allele from Patient 2 started to grow, indicating that the D148N mutation produces a thermolabile enzyme (Fig. 2A, lane 4). Yeast carrying the paternal allele from Patient 1, resulting in the R123Q PMM (Fig. 2A and B, lane 3), was not able to survive at either temperature. However, it is obvious from this growth experiment that the C241S, C9Y, and L32R mutations do not 


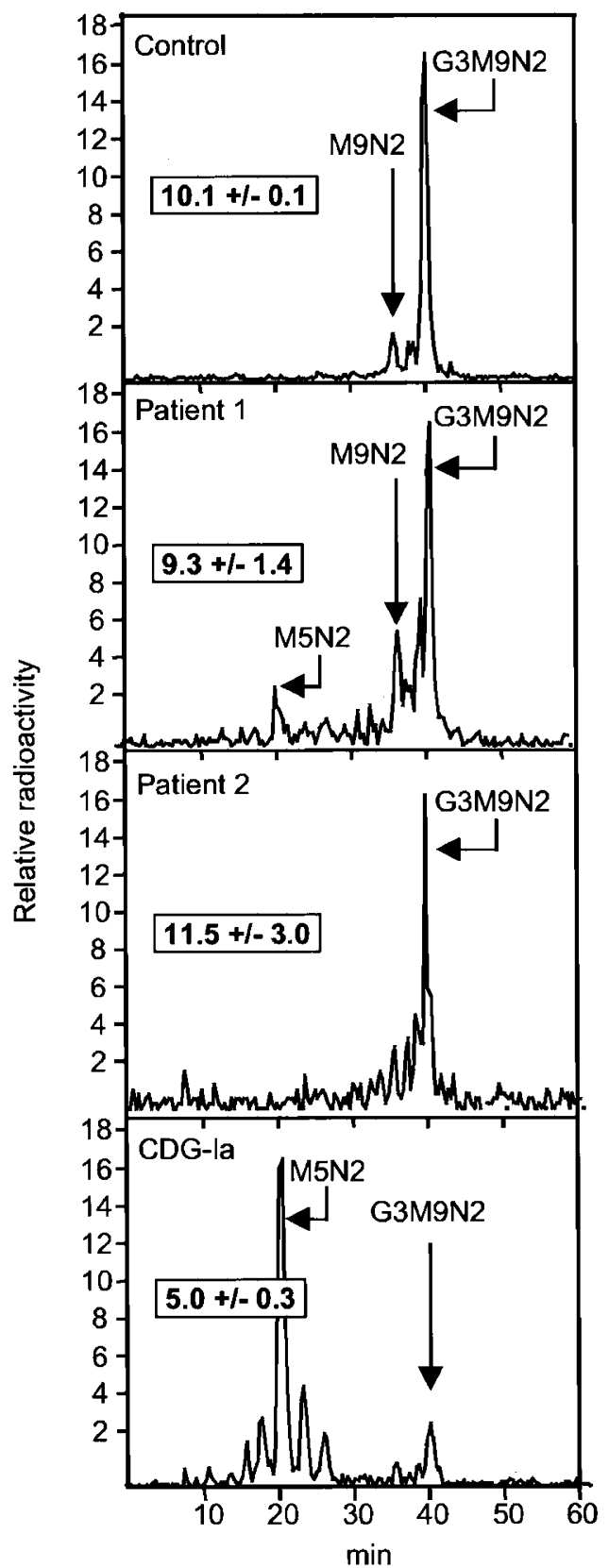

Fig. 1 HPLC analysis of the LLO. Fibroblasts from control patients and established CDG-Ia patients were labeled for 1 hour with $\left[2-{ }^{3} \mathrm{H}\right]$ mannose in medium containing 0.5 $\mathrm{mM}$ glucose. The LLO was isolated, hydrolyzed from the lipid carrier, and analyzed by amine adsorption HPLC to separate the oligosaccharides based on their size. Upper panel shows the elution profile from control cells. The main peak coelutes with a radiolabeled standard $\mathrm{Glc}_{3}\left[2-{ }^{3} \mathrm{H}\right] \mathrm{Man}_{9} \mathrm{GlcNAc}_{2}$ (G3M9N2), whereas the minor peak coelutes with $\left[2-{ }^{3} \mathrm{H}\right] \mathrm{Man}_{9} \mathrm{GlcNAc}_{2}$ (M9N2) purified from an ALG6-deficient yeast. The two middle panels show the LLO profile from Patient 1 and 2, respectively, showing normal pattern, whereas the main peak in the LLO profile from typical CDG-Ia patients coelutes with the $\left[2-{ }^{3} \mathrm{H}\right] \mathrm{Man}_{5} \mathrm{GlcNAc}_{2}$ (M5N2) standard. Inserted numbers in bold are the average \pm of 3 independent experiments of the ratios between incorporated amounts of $\left[2-{ }^{3} \mathrm{H}\right]$ mannose into glycoprotein and ${ }^{35} \mathrm{~S}$-methionine.

change the ability of PMM to complement the sec5 $3^{\text {ts }}$ phenotype and, thus, must be considered as very mild mutations. However, it is not known how much PMM activity is needed for survival and growth in yeast; therefore, we also measured the specific activity of the expressed PMMs.

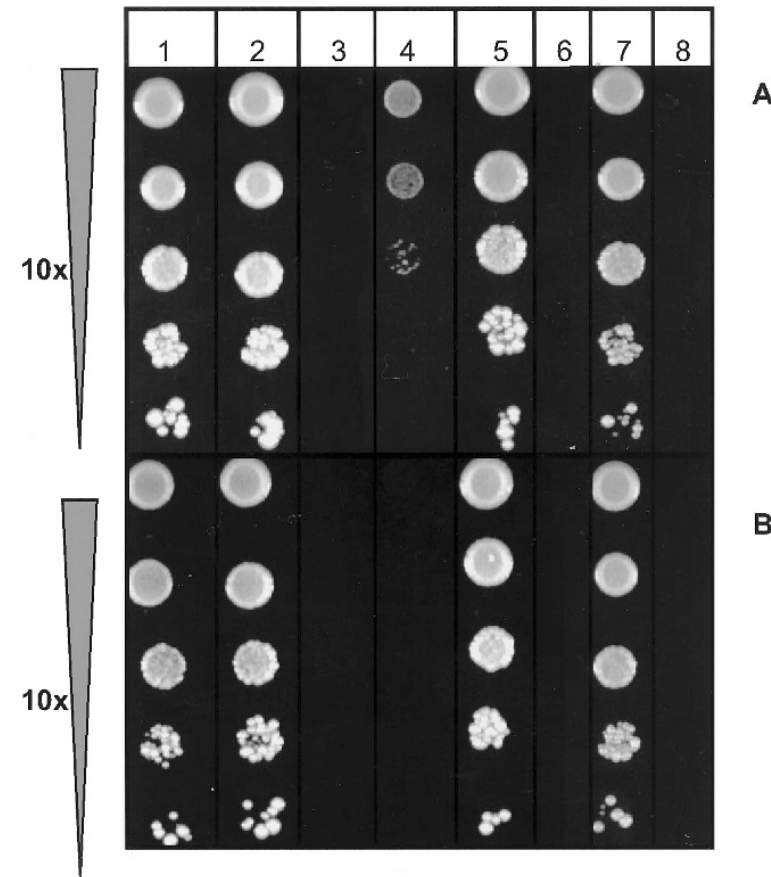

Fig. 2 Complementation of Saccharomyces cerevisiae sec5 $3^{\text {ts }}$ mutant strain with different $P M M 2 \mathrm{cDNAs}$. Plates were incubated at $37^{\circ} \mathrm{C}$ for 40 hours before divided into two sets. One set was transferred to $30^{\circ} \mathrm{C}(\mathrm{A})$, whereas the other set remained at $37^{\circ} \mathrm{C}(\mathrm{B})$. Lane 1 : complementation with wild-type human $P M M 2$; lane 2: 722G $>C$ C PMM2 encoding the maternal C241S mutation from Patient 1; lane 3: 368G $>$ A paternal allele to Patient 2, resulting in the R123Q protein; lane 4: 442G>A PMM2 encoding Patient 2's maternal D148N mutation; lane 5: 26G $>$ A resulting in C9Y paternal PMM2 allele; lane 6: $\Delta \mathrm{c} 24$ mutation resulting in frameshift; lane 7: $95 \mathrm{~T}>\mathrm{G}$ and $96 \mathrm{~A}>\mathrm{C}$ resulting in $\mathrm{L} 32 \mathrm{R}$; lane 8: no PMM2. Starting from the top, 10 -fold dilutions of $\sim 500,000$ cells were plated on SC-URA plates and incubated for an additional 40 hours before being photographed.

\section{Expression and characterization of wild-type and mutant PMM2 in S. cerevisiae}

To address the influence of the various PMM2 mutations in on the activity of the enzyme in a eukaryotic system, we expressed the proteins in PMM-deficient yeast and measured the activity in the extracts. Figure 3 shows the activities expressed as percent of normal wild type human PMM activity. The plasmid carrying the common mutation $\mathrm{R} 141 \mathrm{H}^{40,41}$ gave the same activity as the vector without insert. This finding is expected, because this mutation is believed to be lethal in the homozygous state. ${ }^{41}$ The three mild mutations (C241S, C9Y, and L32R) still showed a significant amount of activity compared with the more severe mutations (R123Q, D148N, and $\Delta \mathrm{c} 24$ ) even though they were below wild-type levels. The mild mutations recently have been expressed in $E$. coli with results comparable to ours. ${ }^{42}$

\section{DISCUSSION}

Synthesis of a typical biantennary N-linked oligosaccharide chain probably requires over 50 gene products specific for glycosylation. At least 30 of these genes are used to assemble and transfer LLO to proteins. Mutations in nine genes that affect $\mathrm{N}$-glycosylation have been shown to cause various types of 


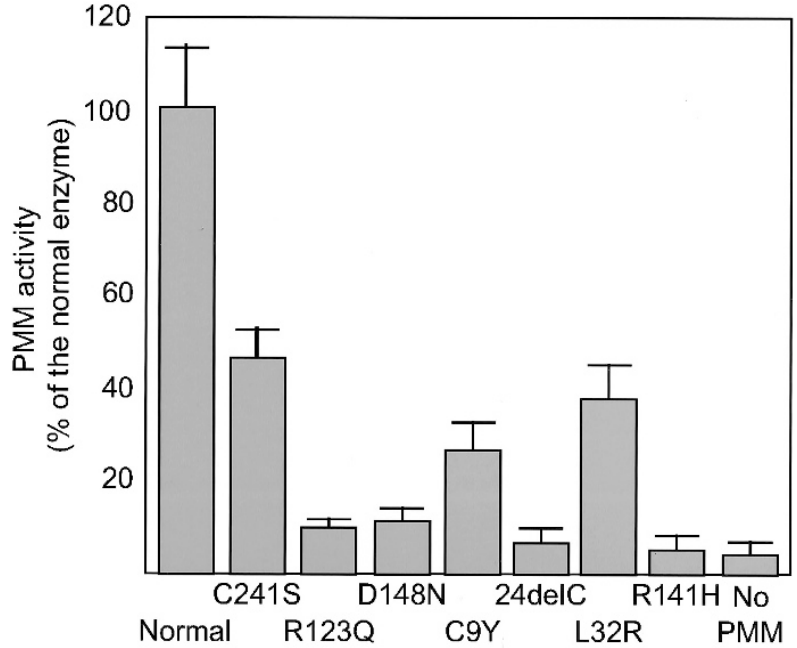

Fig. 3 Relative PMM activity from a Saccharomyces cerevisiae $\sec 53^{\text {ts }}$ strain expressing the $P M M 2$ alleles. Grown and assayed at $37^{\circ} \mathrm{C}$ when possible. The severe mutations had to be grown at permissive temperature, incubated at $37^{\circ} \mathrm{C}$ for 30 minutes to inactivate endogenous PMM. The remaining activity was linear for the duration of the experiment. The activities are expressed as percent of normal human PMM, which was approximately $8.0 \mathrm{~nm} / \mathrm{min}$ per $\mathrm{mg}$ protein.

CDG, ${ }^{9,43}$ and essentially all reported CDG cases have two mutations in a single affected gene leading to the disorder.5,15,44

Because most of the consequences of CDG are thought to result from hypoglycosylation of proteins, i.e., the same endpoint for each disease, the broad spectrum of clinical presentations is surprising. The one exception is that the most common PMM2 mutation $(\mathrm{R} 141 \mathrm{H})$ is apparently lethal when homozygous. ${ }^{41}$ Most CDG-Ia patients have $0 \%$ to $10 \%$ normal PMM activity $21,22,31,32$ and their asymptomatic parents have $\sim 50 \%$ residual activity. One remarkably mild case has approximately $15 \%$ residual activity resulting from mutations in both parental alleles. ${ }^{33}$

Here, we report patients with PMM activities not far below the heterozygous range. The fact that the patients showed substantial amounts of residual PMM activity and had normal levels of glycosylation and normal LLO structure in fibroblasts was puzzling. This finding raises the question of why these children are affected while other parents with 50\% residual PMM activity are not. One explanation is that there is a sharp boundary slightly below 50\% PMM activity that differentiates "symptomatic and nonsymptomatic" phenotypes. ${ }^{45,46}$ There may be a range of affected target organs analogous to the ocular disorders seen in non-nephropathic cystinosis. ${ }^{47}$ In these cases, a serious mutation is paired with a relatively mild one producing a mild phenotype. Another explanation is that other genes, i.e., the genetic background, together with environmental factors contribute to the clinical diversity of this disease. We cannot distinguish between these possibilities at present.

A recent review speculates that limited glycosylation may have a selective advantage. ${ }^{48}$ When we sequenced ALG6 from these patients, Patients 1 and 2 both showed a heterozygous amino acid change F304S, whereas this mutation was not present in Patient 3 (DNA was not available for Patient 4).
ALG6 is required to synthesize an LLO, which is efficiently transferred to proteins in the lumen of the endoplasmic reticulum. ${ }^{48}$ Even mild heterozygous mutations, such as this one or ones in other such genes, may reduce glycosylation. The phenotypic impact of such mutations would depend on the specific tissue, time of growth or development, and the demand for glycosylated proteins.

Environmental conditions and stresses can also reveal the effects of such mutations. For instance, one CDG-Ic patient lacked heparan sulfate proteoglycan on small intestine enterocytes and developed protein-losing enteropathy only during viral-induced gastroenteritis. ${ }^{20}$ The amount and distribution of heparan sulfate improved in the small intestine after recovery, but it was always normal in the more slowly turning over cells in the stomach, esophagus, and colon. Localized proliferation in response to infection seemed to tax the already compromised glycosylation apparatus, leading to enteral protein loss. ${ }^{20}$ Other stresses, such as maternal fever during critical gestational periods could affect thermolabile glycosylation phenotypes. Inadequate maternal or fetal nutrition could contribute additional environmental stress. Both mannose and fucose supplements have been used to treat CDG patients, ${ }^{24,49,50}$ showing that these sugars can have a therapeutic effect. An inadequate supply can contribute to clinical phenotype in susceptible patients.

In summary, we have identified a new mutation in PMM2 and shown that some mildly affected patients have substantial PMM activity. A genotype-phenotype correlation is beginning to emerge ${ }^{16,51}$ for some mildly affected CDG-Ia patients. However, our work also suggests that there is a high threshold for nonsymptomatic PMM deficiency and/or that other genes involved with glycosylation may contribute.

\section{Acknowledgments}

This work was supported by a grant from the "CDG Parents Network Foundation," as well as March of Dimes Grant FY99205 and NIH R01 DK55615 (H.H.F.). V.W. was supported by fellowship 990059/20 from the Carlsberg Foundation and Biotechnology Research and Training Grant from the University of California, San Diego. We are indebted to the past and present members of the lab, especially Dr. Geetha Srikrishna, Violet Abraham, Angelica Romero, and Patty Lucker, for their help, useful discussions, and initial experiments. Special thanks go to the patients and their families for their patience and support. Dr. Randy Schekman is gratefully acknowledged for yeast strains.

\section{References}

1. Matthijs G, Schollen E, Pardon E, Veiga-Da-Cunha M, Jaeken J, Cassiman JJ, Van Schaftingen E. Mutations in PMM2, a phosphomannomutase gene on chromosome $16 \mathrm{p} 13$, in carbohydrate-deficient glycoprotein type I syndrome (Jaeken syndrome). Nat Genet 1997;16:88-92.

2. Rush JS, Panneerselvam K, Waechter CJ, Freeze HH. Mannose supplementation corrects GDP-mannose deficiency in cultured fibroblasts from some patients with congenital disorders of glycosylation (CDG). Glycobiology 2000;10:829-835.

3. Westphal V, Schottstadt C, Marquardt T, Freeze HH. Analysis of multiple mutations in the hALG6 gene in a patient with congenital disorder of glycosylation Ic. Mol Genet Metab 2000;70:219-223. 
4. Imbach T, Burda P, Kuhnert P, Wevers RA, Aebi M, Berger EG, Hennet T. A mutation in the human ortholog of the Saccharomyces cerevisiae ALG6 gene causes carbohydrate-deficient glycoprotein syndrome type-Ic. Proc Natl Acad Sci USA 1999;96:6982-6987.

5. Imbach T, Grnewald S, Schenk B, Burda P, Schollen E, Wevers RA, Jaeken J, de Klerk JBC, Berger EG, Matthijs G, Aebi M, Hennet T. Multi-allelic origin of congenital disorder of glycosylation (CDG)-Ic. Hum Genet 2000;106:538-545.

6. Burda P, Borsig L, de Rijk-van Andel J, Wevers R, Jaeken J, Carchon H, Berger EG, Aebi M. A novel carbohydrate-deficient glycoprotein syndrome characterized by a deficiency in glucosylation of the dolichol-linked oligosaccharide. J Clin Invest 1998;102:647-652.

7. Runge KW, Huffaker TC, Robbins PW. Two yeast mutations in glucosylation steps of the asparagine glycosylation pathway. J Biol Chem 1984;259:412-417.

8. Reiss G, te Heesen S, Zimmerman J, Robbins PW, Aebi M. Isolation of the ALG6 locus of Saccharomyces cerevisiae required for glucosylation in the N-linked glycosylation pathway. Glycobiology 1996;6:493-498.

9. Westphal V, Srikrishna G, Freeze HH. Congenital disorders of glycosylation: have you encountered them? Genet Med 2000;2:329-337.

10. Jaeken J, Matthijs G, Carchon H, Van Schaftingen E. Defects of N-Glycan Synthesis. In: Scriver CR, Beaudet AL, Sly WS, Valle D, editors. The metabolic \& molecular bases of inherited diseases. Vol. 1, Part 7: Carbohydrates. New York: McGraw-Hill, Medical Publishing Division, 2001:1601-1622.

11. Jaeken J, Carchon H. The carbohydrate-deficient glycoprotein syndromes: an overview. J Inherit Metab Dis 1993;16:813-820.

12. Grunewald S, Imbach T, Huijben K, Rubio-Gozalbo ME, Verrips A, de Klerk JB, Stroink H, de Rijk-van Andel JF, Van Hove JL, Wendel U, Matthijs G, Hennet T, Jaeken J, Wevers RA. Clinical and biochemical characteristics of congenital disorder of glycosylation type Ic, the first recognized endoplasmic reticulum defect in $\mathrm{N}$ glycan synthesis. Ann Neurol 2000;47:776-781.

13. Jaeken J, Matthijs G, Barone R, Carchon H. Carbohydrate deficient glycoprotein (CDG) syndrome type I. J Med Genet 1997;34:73-76.

14. Kristiansson B, Stibler H, Conradi N, Eriksson BO, Ryd W. The heart and pericardial effusions in CDGS-I (carbohydrate-deficient glycoprotein syndrome type I). J Inherit Metab Dis 1998;21:112-124.

15. Matthijs G, Schollen E, Bjursell C, Erlandson A, Freeze H, Imtiaz F, Kjaergaard S, Martinsson T, Schwartz M, Seta N, Vuillaumier-Barrot S, Westphal V, Winchester B. Mutations in PMM2 that cause congenital disorders of glycosylation, type Ia (CDG-Ia). Hum Mutat 2000;16:386-394.

16. Grunewald S, Schollen E, Van Schaftingen E, Jaeken J, Matthijs G. High residual activity of PMM2 in patients' fibroblasts: possible pitfall in the diagnosis of CDG-Ia (phosphomannomutase deficiency). Am J Hum Genet 2001;68:347-354.

17. Sherman F. Getting started with yeast. Methods Enzymol 1991;194:3-21.

18. Sambrook J, Fritsch EF, Maniatis T. Molecular cloning: a laboratory manual, 2nd Ed. In: Fritsch EF, Maniatis T, editors. Laboratory manuals series. New York: Cold Spring Harbor Laboratory Press, 1989.

19. Kepes F, Schekman R. The yeast SEC53 gene encodes phosphomannomutase. J Biol Chem 1988;263:9155-9161.

20. Kim S, Westphal V, Srikrishna G, Mehta DP, Peterson S, Filiano J, Karnes PS, Patterson MC, Freeze HH. Dolichol phosphate mannose synthase (DPM1) mutations define congenital disorder of glycosylation Ie (CDG-Ie). J Clin Invest 2000;105:191-198.

21. Van Schaftingen E, Jaeken J. Phosphomannomutase deficiency is a cause of carbohydrate-deficient glycoprotein syndrome type I. FEBS Lett 1995;377:318-320.

22. Panneerselvam K, Etchison JR, Skovby F, Freeze HH. Abnormal metabolism of mannose in families with carbohydrate-deficient glycoprotein syndrome type 1 . Biochem Mol Med 1997;61:161-167.

23. Westphal V, Kjaergaard S, Davis JA, Peterson SM, Skovby F, Freeze HH. Genetic and metabolic analysis of the first adult with congenital disorder of glycosylation type Ib: long-term outcome and effects of mannose supplementation. Mol Genet Metab 2001;73:77-85.

24. Niehues R, Hasilik M, Alton G, Korner C, Schiebe-Sukumar M, Koch HG, Zimmer KP, Wu R, Harms E, Reiter K, von Figura K, Freeze HH, Harms HK, Marquardt T. Carbohydrate-deficient glycoprotein syndrome type $\mathrm{Ib}$. Phosphomannose isomerase deficiency and mannose therapy. J Clin Invest 1998;101:1414-1420.

25. Westphal V, Enns GM, McCracken MF, Freeze HH. Functional analysis of novel mutations in a congenital disorder of glycosylation Ia patient with mixed Asian ancestry. Mol Genet Metab 2001;73:71-76.

26. Jaeken J, Stibler H, Hagberg B. The carbohydrate-deficient glycoprotein syndrome. A new inherited multisystemic disease with severe nervous system involvement. Acta Paediatr Scand Suppl 1991;375:1-71.

27. Krasnewich D, Gahl WA. Carbohydrate-deficient glycoprotein syndrome. Adv Pediatr 1997;44:109-140.

28. Kristiansson B, Borulf S, Conradi N, Erlanson-Albertsson C, Ryd W, Stibler H. Intestinal, pancreatic and hepatic involvement in carbohydrate-deficient glycoprotein syndrome type I. J Pediatr Gastroenterol Nutr 1998;27:23-29.
29. Stibler H, Blennow G, Kristiansson B, Lindehammer H, Hagberg B. Carbohydratedeficient glycoprotein syndrome: clinical expression in adults with a new metabolic disease. J Neurol Neurosurg Psychiatry 1994;57:552-556.

30. Jaeken J, Matthijs G, Saudubray JM, Dionisi-Vici C, Bertini E, de Lonlay P, Henri H, Carchon H, Schollen E, Van Schaftingen E. Phosphomannose isomerase deficiency: a carbohydrate-deficient glycoprotein syndrome with hepatic-intestinal presentation. Am J Hum Genet 1998;62:1535-1539.

31. Jaeken J, Carchon H. What's new in congenital disorders of glycosylation? Eur J Paediatr Neurol 2000;4:163-167.

32. Carchon H, Van Schaftingen E, Matthijs G, Jaeken J. Carbohydrate-deficient glycoprotein syndrome type Ia (phosphomannomutase-deficiency). Biochim Biophys Acta 1999;1455:155-165.

33. van Ommen CH, Peters M, Barth PG, Vreken P, Wanders RJ, Jaeken J. Carbohydrate-deficient glycoprotein syndrome type Ia: a variant phenotype with borderline cognitive dysfunction, cerebellar hypoplasia, and coagulation disturbances. J Pediatr 2000;136:400-403.

34. Krasnewich DM, Holt GD, Brantly M, Skovby F, Redwine J, Gahl WA. Abnormal synthesis of dolichol-linked oligosaccharides in carbohydrate-deficient glycoprotein syndrome. Glycobiology 1995;5:503-510.

35. Korner C, Lehle L, von Figura K. Carbohydrate-deficient glycoprotein syndrome type 1: correction of the glycosylation defect by deprivation of glucose or supplementation of mannose. Glycoconj J 1998;15:499-505.

36. Panneerselvam K, Freeze HH. Mannose corrects altered N-glycosylation in carbohydrate-deficient glycoprotein syndrome fibroblasts. J Clin Invest 1996;97:1478-1487.

37. Imbach T, Schenk B, Schollen E, Burda P, Stutz A, Grunewald S, Bailie NM, King MD, Jaeken J, Matthijs G, Berger EG, Aebi M, Hennet T. Deficiency of dolicholphosphate-mannose synthase-1 causes congenital disorder of glycosylation type Ie. J Clin Invest 2000;105:233-239.

38. Matthijs G, Schollen E, Pirard M, Budarf ML, Van Schaftingen E, Cassiman JJ. PMM (PMM1), the human homologue of SEC53 or yeast phosphomannomutase, is localized on chromosome 22q13. Genomics 1997;40:41-47.

39. Feldman RI, Bernstein M, Schekman R. Product of SEC53 is required for folding and glycosylation of secretory proteins in the lumen of the yeast endoplasmic reticulum. J Biol Chem 1987;262:9332-9339.

40. Kjaergaard S, Skovby F, Schwartz M. Absence of homozygosity for predominant mutations in PMM2 in Danish patients with carbohydrate-deficient glycoprotein syndrome type 1. Eur J Hum Genet 1998;6:331-336.

41. Matthijs G, Schollen E, Van Schaftingen E, Cassiman JJ, Jaeken J. Lack of homozygotes for the most frequent disease allele in carbohydrate-deficient glycoprotein syndrome type 1a. Am J Hum Genet 1998;62:542-550.

42. Vuillaumier-Barrot S, Hetet G, Barnier A, Dupre T, Cuer M, de Lonlay P, CormierDaire V, Durand G, Grandchamp B, Seta N. Identification of four novel PMM2 mutations in congenital disorders of glycosylation (CDG) Ia French patients. J Med Genet 2000;37:579-580.

43. Aebi M, Hennet T. Congenital disorders of glycosylation: genetic model systems lead the way. Trends Cell Biol 2001;11:136-141.

44. Schollen E, Dorland L, de Koning TJ, Van Diggelen OP, Huijmans JG, Marquardt T, Babovic-Vuksanovic D, Patterson M, Imtiaz F, Winchester B, Adamowicz M, Pronicka E, Freeze H, Matthijs G. Genomic organization of the human phosphomannose isomerase (MPI) gene and mutation analysis in patients with congenital disorders of glycosylation type Ib (CDG-Ib). Hum Mutat 2000;16:247-252.

45. Dipple KM, McCabe ER. Phenotypes of patients with "simple" Mendelian disorders are complex traits: thresholds, modifiers, and systems dynamics. Am J Hum Genet 2000;66:1729-1735.

46. Rao DC. Genetic dissection of complex traits: an overview. Adv Genet 2001;42:13-34.

47. Anikster Y, Lucero C, Guo J, Huizing M, Shotelersuk V, Bernardini I, McDowell G, Iwata F, Kaiser-Kupfer MI, Jaffe R, Thoene J, Schneider JA, Gahl WA. Ocular nonnephropathic cystinosis: clinical, biochemical, and molecular correlations. Pediatr Res 2000;47:17-23.

48. Freeze HH, Westphal V. Balancing N-linked glycosylation to avoid disease. Biochimie 2001;83:791-799.

49. Babovic-Vuksanovic D, Patterson MC, Schwenk WF, O'Brien JF, Vockley J, Freeze $\mathrm{HH}$, Mehta DP, Michels VV. Severe hypoglycemia as a presenting symptom of carbohydrate-deficient glycoprotein syndrome. J Pediatr 1999;135:775-781.

50. Marquardt T, Luhn K, Srikrishna G, Freeze HH, Harms E, Vestweber D. Correction of leukocyte adhesion deficiency type II with oral fucose. Blood 1999;94:3976-3985.

51. de Lonlay P, Seta N, Barrot S, Chabrol B, Drouin V, Gabriel BM, Journel H, Kretz M, Laurent J, Le Merrer M, Leroy A, Pedespan D, Sarda P, Villeneuve N, Schmitz J, van Schaftingen E, Matthijs G, Jaeken J, Korner C, Munnich A, Saudubray JM, CormierDaire V. A broad spectrum of clinical presentations in congenital disorders of glycosylation I: a series of 26 cases. J Med Genet 2001;38:14-19. 